\title{
Taxation, expenditure, and accountability. Lessons from Namibia
}

Dirk Hansohm, Klaus Schade and Maano Nepembe

\section{Introduction}

Is taxation the basis - or a basis - for a relationship of accountability between government and citizenry? 'No representation, no taxation'? It has long been a concern of economic theory that the excessive inflow of a free or cheap resource into an economy the might bring ruin - the 'resource curse'. Economists have also seen taxation as one of a number of 'agencies of restraint', that enable an agent to bind himself to a particular course of action, whose weakness in Africa is a cause of stagnation (Collier 1995) . Political scientists increasingly argue that governments that rely to a high degree on non-tax incomes - i.e. aid, mineral rents - tend to be unaccountable. Moore terms these non-tax incomes 'unearned' and suggests that 'The more government income is 'earned', the more likely are state-society relations to be characterised by accountability, responsiveness, and democracy' (1998: 95). Our purpose here is to test his thesis for the case of Namibia. The results are the basis of a discussion of the strengths, limits and possible extensions of the model.

Moore puts forward two criteria to judge the degree to which state income is earned:

- Organisational effort ('how large, elaborate, differentiated, and efficient is the bureaucratic apparatus that the state deploys to collect its income?')

- Reciprocity ('how far are citizens obtaining some reciprocal services in return for their tax contributions?').

We focus on the reciprocity argument and extend it to the dimension of income distribution. Moore (1998) treats 'citizens' as a homogenous category. We argue that it may be useful - or even necessary - to distinguish between groups of taxpayers. The more unequal societies are, the more there may be significant differences among citizens, in respect the extent of both tax payments and benefits from public expenditures. This is very much the case in Namibia, where most of the taxes are borne by the 'white' formal business sector and the emerging 'black elite', principally government employees, while major benefits go, through social expenditures, to those who pay few 
taxes. In addition, there are in Namibia substantial regional inequalities in public expenditure, and most of the population pay sizeable indirect taxes.

The next section provides a background on Namibia's economy and society, followed by an analysis of Namibia's tax base. We then consider who pays taxes and who benefits from public expenditures. This leads to a discussion of accountability in Namibia, and conclusions about the Moore thesis.

\section{Namibia's economy and society}

Namibia's per capita gross national income of US\$ 2050 in 2000 (World Bank 2002) puts it well beyond the group of low income countries (with an average per capita income of US\$ 420) to which 38 of the 48 sub-Saharan African countries belong. However, the economy has been almost stagnant, with an average growth rate of $0.3 \%$ over the five years 1996 to2001. In contrast, the average low-income country grew at a rate exceeding $3 \%$ in that period. Does this indicate that Namibia may be on the way of joining the 'fourth world'?

Namibia's high average income is very unequally distributed. The Gini coefficient of income inequality - 0.7 - is one of the highest of the world. The richest $1 \%$ of households in Namibia earn more than the entire poorest $50 \%$ of households (NEPRU 1999). More than half of the population lives on less than US\$ 2 per day (World Bank 2002). In other words, the majority of the population lives in the fourth world. There are two important sources of Namibia's severe poverty and inequality. One is the heritage of the previous apartheid system of institutionalised discrimination. This resulted in a high correlation between income and ethnic identity, which in turn led to high regional differences. Although Namibia is in its twelfth year of independence, this takes time to overcome. The other source is the economic distortions that are virtually inherent to mineral economies: high 'rent' incomes that are concentrated in the hands of government and a small number of economic agents.

\section{Namibia's tax base}


In contrast to the typical 'Fourth World' country (Moore, 1998), Namibia has a high ratio of tax revenue to GDP. At around 30\%, this is well above the average for low and middle-income countries. On a per capita basis, Namibia is also one of the highest recipients of foreign aid. In 1999, it received US\$ 104 per capita, compared with an average of US\$ 9 of all lower middleincome countries and compared to US\$ 20 for sub-Saharan Africa. On average, foreign aid has contributed $14 \%$ to the National Budget over the past ten years - slightly more than the average lower middle-income country.

Moore (1998:100) classifies the sources of state revenue according to the degree of 'earnedness' (Table 1). Foreign aid is classified as having a very low degree of earnedness. Next come taxes on international trade and transactions, followed by non-tax revenue, domestic taxes on goods and services, and other taxes. The highest degrees of earnedness is attributed to taxes on income, profit, and capital gains and social security contributions. The mobilisation of foreign aid requires very little organisational effort, and reciprocity to citizens does not apply, as foreign aid is not paid by them however, there is a degree of expectation from the donors of foreign aid. The collection of taxes on international trade requires limited effort, while there is little expectation of reciprocity on the part of taxpayers, as they are little aware of their payment. On the other extreme, taxes on income need a high effort to extract, and the taxpayers have a high degree of reciprocal expectations. A strikingly clear picture emerges, when comparing country groups, defined by their income levels (Table 1): the poorer the country, the higher the reliance on 'unearned income' (aid, taxes on trade). Conversely, the richer a country, the more important are highly earned state incomes (taxes on income and profits, social security contributions).

\section{(Insert Table 1 about here)}

Where does Namibia fit into this picture? Income wise, the country belongs in the category of lower middle income countries (column 3 of Table 1). The importance of foreign aid to Namibia is slightly higher than in the comparison group. The importance of taxes on international trade is extraordinarily 
high in Namibia, much higher than that of any country group. In addition, this tax is even more 'unearned' than elsewhere, as most of it is simply transferred from South Africa's coffers, because of Namibia's membership in the Southern African Customs Union (SACU). Overall, using Moore's classification of the degree of earnedness of different types of state income, Namibia is broadly typical of the average of all lower middle income countries.

However, there is at least one problem with this classification. It is questionable whether profit taxes levied on mining companies - a significant source of state income - should be considered as 'high' in respect of earned-ness. Income from mining companies - in particular diamond mining companies is earned by the government to much lesser degree than other sub-categories of taxes on income and profit. No negotiation with citizens is necessary to exploit this income source.

\section{Who pays taxes?}

As seen in Table 1, Namibia's tax system has three primary tax bases: the income and profits tax, the consumption tax, and the international trade and transactions tax. The income and profits tax is applied to all individual income over $\mathrm{N} \$ 20,000$ ( $\mathrm{N} \$=$ Namibian dollars) and to corporate profits. There are about 200,000 individual taxpayers in the country and an additional 15,000 companies. Individual taxpayers are made up of government and other formal sector employees. There are around 80,000 government employees. A considerable proportion of them do not pay taxes since their income does not exceed the tax threshold of $\mathrm{N} \$ 20,000$ per annum. Revenue from the income and profits tax has increased in significance over the years, contributing now almost $20 \%$ of total income. This is not necessarily the result of an increased efficiency in the tax collection system. It is also the result of inflation-based salary increments and a larger public sector.

Companies are put in three categories for tax purposes. Non-mining operations are taxed at a flat rate of $35 \%$ of taxable income. Diamond mining operations are taxed at 55\%, while other mining operations are taxed according to a rather complicated formula, but with a minimum of $25 \%$. Furthermore, companies granted Export Processing Zone status do not pay company taxes or 
import duties. Finally, registered manufacturers and exporters of manufactured products benefit from further tax incentives, some of which are individually negotiable. The complexity of this tax system reduces transparency and subsequently the accountability of government towards its citizens. ${ }^{1}$

In general, the tax system is based on a quasi-voluntary compliance (Rakner, 2001) since there are not even a handful of tax controllers in the country. Together with high tax rates, this gives high incentives for tax evasion. The efforts of governments to collect taxes can be classified as limited. The majority of the population - and of the poor - lives in north of the country. They are mainly subsistence farmers and informal-sector employees. The government has its political base here. It is sometimes labelled a 'tax free zone'. It is much easier to control a few entry points to collect taxes on international trade, and even there little effort is needed since Namibia receives this revenue from a share in a pool collected by Southern African Customs Union (SACU) - to which South Africa contributes the largest proportion. Tax collection efforts are increasing with tax offices set up in more regions and awareness campaigns - in particular in the North - initiated to explain the rationale behind taxation. These initiatives can be seen as efforts to close tax loopholes. However, they are also rooted in the realisation that income from international trade will eventually decline owing to trade liberalisation.

The second main tax base, the consumption tax, is the recently implemented value-added tax (VAT), which replaced the general sales tax (GST) and additional sales levy (ASL) in 2000. The VAT raises about a quarter of total government revenue. Most products are taxed at a rate of $15 \%$, while a small portion of goods and services are taxed at the luxury rate of $30 \%$, and certain staples are exempt from taxation or are taxed at a zero rate. As all consumers pay VAT on nearly all products, the consumption tax base is effectively quite wide. Low-income consumers devote a

${ }^{1}$ It can also be argued that Namibia's overcomplex system of company taxation, including a myriad of exemptions to promote specific sectors, cheapens the cost of capital relative to that of labour in many sectors. 
greater share of their income to consumption, and therefore a greater share of their income to VAT. This is qualified by the fact that the very poor live in rural areas and consume to a higher degree maize meal and mahangu (millet) that are exempted from VAT. Nevertheless, unlike many developing countries, everybody - including 'subsistence farmers' - is highly integrated into the market system and dependent on taxed goods. Thus, the consumption tax is a regressive tax.

The third main tax base, the international trade and transactions tax, generates about $30 \%$ of government tax revenue, primarily through SACU revenue. In recent years, Namibia's dependence on this tax has increased; in 1995 Namibia relied on tariff income for only $20 \%$ of total government revenue. The Medium Term Budget Framework estimates that the government's dependence on this tax will continue. The share of total tax revenue generated from this source is forecast to reach $32 \%$ in 2003 . Due to the high number of products exposed to tariffs (approximately 7,800 tariff lines), this tax is indirectly paid by Namibian consumers, and is considered to have a relatively wide tax base as the tariff affects a large proportion of goods in the domestic economy. Tariff taxes place a substantial tax burden on low-income Namibians. Because Namibia's import intensity of goods purchased by poor and rural consumers is high, all Namibians experience the indirect tax burden of tariffs. In addition, analysis of the tariff lines shows a bias against goods commonly purchased by low-income Namibians. The average tariff for a consumption basket comprised of food, medicine, clothing, and basic hygiene imports carries an average weighted tariff of $13 \%$, while the average weighted tariff for all tariff lines was $8 \%{ }^{2}$.

In a nutshell, a small group of the population pays direct taxes, but indirect taxes are borne by many. Tax collection efforts are relatively low since significant proportions are derived from the SACU pool, from public and formal sector employees as well as formal businesses in the commercial and industrial centres of the country.

${ }^{2}$ Our data comprised the top $80 \%$ of imports by value. The lowest $20 \%$ of imports, and the corresponding tariff lines, were excluded from analysis. 


\section{Who benefits from expenditures?}

Government expenditure patterns reflect attempts to redress social imbalances created in the past. Education, health and social services have absorbed the main chunks of the national budget annually about $40 \%$ since independence (Figure 1). Spending priorities in social sectors and, more specifically in rural areas that were without adequate social infrastructure at independence can be seen as a redistribution of wealth.

(Figure 1 about here)

As poverty is mainly rural and differs significantly by region, a look at the regional distribution of wealth and expenditure over time is interesting. It shows that both the levels of income and of public expenditure have moved slowly but surely towards a more balanced picture. Per capita development expenditure has moved strongly upwards in the lagging regions. Adjusted incomes for the poorest region (Ohangwena) have reached $85 \%$ of the national average according to most recent figures.

\section{(Table 2 about here)}

Namibia devotes an exceptionally high share of public expenditure to education. It exceeds $9 \%$ of GNP, and is more than double the average for countries with comparable incomes. This appears appropriate in the light of the importance of skills, and thus education, as a basis for economic growth. However, the efficiency of the expenditure on education remains limited, as shown by the high rates of dropout and repetition of students. Expenditure on education is also broadly pro-poor, as education is an important way out of poverty. There are however some important qualifications: the high subsidisation of tertiary education - which has, in contrast to basic education, higher private than social returns, and should thus be paid privately; persistent regional inequities to the detriment of 
the poorer regions; and limited attention to needs of the labour market, with too much focus on administrative skills, and too little emphasis on vocational training and entrepreneurship.

Namibia's health expenditure is also exceptionally high: more than double of the sub-Saharan African average. This is again broadly pro-poor: directly by improving the living standard of the poor, and indirectly by improving the quality of the labour force. Health indicators like infant mortality rates are showing improvement. However, there are limitations to the poverty orientation of health spending: limited accessibility of health services for many poor people; and continuing regional inequalities, again to the detriment of the poorer regions.

Namibia has a non-contributory pension scheme. Every elderly, blind or disabled person is eligible to a monthly pension of $\mathrm{N} \$ 200$. This scheme is of major importance for poverty alleviation. It is a major income source for the poor, reaching through the channel of the extended family far beyond the beneficiaries. However, the pension is quite small, compared to more than 3 times as much in South Africa. Furthermore, its level has not keep pace with inflation, so that it has fallen in real terms. The drawbacks in terms of poverty alleviation are that: it is not targeted - the non-poor also benefit; and not all eligible persons receive their benefits - especially the poorest in outlying rural areas.

Another important expenditure for the poor is agricultural subsidies. However, in practice these have not always reached the poor and often proved to have detrimental effects (Hansohm et al. 2001: 175). A study in the northern communal areas found that only about $2 \%$ of farmers received subsidies, and the beneficiaries were not primarily the poorest, but those easily accessible and more vocal. A drought scheme aimed at helping communal farmers to market their cattle proved unsustainable because it led to an increase in cattle.

Housing is also an important expenditure reaching the poor, as it addresses a basic need. Furthermore, it is recognised that building is also an important activity creating employment and income. In the Namibian context, it can be an all-year-round activity. While a lot has been 
achieved, the progress falls far short of the plans and expectations at independence. The backlog of affordable housing units has actually increased since independence. Problems include lack of financial sustainability of housing programmes, insufficient training in self-help projects, lack of community involvement, and lack of institutional sustainability.

The overall picture with respect to the distribution of benefits from government expenditure is that a high portion of social expenditure benefits the poor directly and substantially, but there are problems of access, especially for the very poor, and expenditures are not always efficient..

Looking at taxation and expenditure together, it becomes obvious that, despite all inefficiencies and drawbacks, the fiscal system is having a redistributive effect. How does this relate to accountability? As a high percentage of state revenue comes from 'unearned' income, we should expect a system of low accountability.

\section{Namibia's system of accountability}

Namibia is a representative democracy with one of Africa's most progressive constitutions. It has a parliament with two houses, and an independent judiciary. Other institutions to enforce accountability are the Auditor General and the Ombudsman, both of them independent and autonomous. Governance is strengthened with a free press. The country has three daily newspapers (in three languages) and a number of other independent newspapers and radio stations, in addition to the public Namibian Broadcasting Corporation (NBC). The press in Namibia entertains a lively and critical debate. The other underlying factor of accountability is a strong and lively civil society with organised labour and employer organisations and flourishing NGOs.

However, this picture has to be qualified. The current system of governance represents a radical break with its past of authoritarian and highly discriminatory government (apartheid). It is - not surprisingly - not yet an internalised system that is taken for granted. More importantly, not everyone is making use of it to the same degree. For instance, the business and labour organisations are predominantly organising the 'formal' business sector, excluding the majority living in the 'informal' 
and agricultural sectors. The poor majority, living in the rural areas, is not only less organised, but also less informed and in general participates less in the political process. Furthermore, the business organisations are rather weak. Formerly representing only 'white' business, they are on the way of becoming representative of business as a whole. However, this process is far from completed. For one thing, parts of the emerging 'black' business community feels inadequately represented by the Namibian Chamber of Commerce and Industry (NCCI). The Indigenous People Business Council (IPBC) was founded as a result. For another, the NCCI's membership does not represent the entire 'white' business community. The key channels for business influence on government decision making remain personal and informal.

Other weaknesses in the governance system are:

- The institutions set up to hold government accountable (Ombudsman, Auditor General) are well constituted, but still in their infancy and not sufficiently funded.

- Government decisions are not always transparent.

- The opposition is small and cannot effectively challenge the vast (and increasing) legislative majority of the ruling party.

- The administration of the legal process is slow and not always effectively enforced.

- In general, institutions are weak.

Surprisingly, in light of the high ratio of tax to GNP, tax does not feature prominently in public discussion. Nor is it of key interest in NCCI representations to government. Over the past two years, business has enjoyed a formal, if limited, role in the budgeting process. Government presents its budget framework to a selected group of business leaders and academics for informal comment. These are first steps toward a proper process of formal business-government consultation. But 
informal contacts remain more important. One indicator for this is the numerous tax exemptions given to individual companies.

Although parliament discusses the budget, the key debate takes place earlier within the ruling party, SWAPO, which has a comfortable majority in parliament. NGOs, through their representative body NANGOF (Namibian Non-Government Organisations Federation), perform a limited function in the area of public discussion of fiscal policy. As with the public discussion on fiscal policy in general, the focus is more on aspects of government expenditure (level, distribution, efficiency, and size of deficit) than on revenue raising.

An important aspect of governance is the extent of corruption and the attention now paid to it. Since 1996, Namibia has undertaken an extensive process of examining issues of corruption. This led to a large National Anti-Corruption Conference in 1998. While few of its recommendations were initially implemented, in late 2001 a comprehensive law on corruption was passed by parliament.

\section{Conclusion}

What can we learn from this? Intuitively, the argument about the link between taxation and accountability makes sense - the data collected by Moore (1998) also back it up. On the surface, the Namibian data do not fit the theory: there is substantial accountability of the state to citizens despite the fact that government income is 'earned' to a relatively low degree. However, when we disaggregate citizens by income group, a modified version of Moore's theory becomes plausible. Citizens with low income have less influence. Government is more accountable to those who do pay taxes: the organised interest groups of trade unionised labour, and the formal business sector. 
However, a number of questions and unresolved issues remain. ${ }^{3}$ Much of government's income comes from indirect taxes, on imports and on consumption. Because of the highly integrated and import intensive economy, these taxes are also paid to a high degree by the poor - although they are not very much aware of this. There also does not seem to be a high degree of public awareness of the sources of financing of government expenditures. Although a lot of development expenditure is financed by foreign aid, this does not seem to be publicly perceived. There is a need to do research on perceptions. Surprisingly, in the public discussion in Namibia taxes hardly play a role - despite the fact that we have a high tax take, as noted above. A lot of taxes, especially those on consumption and trade, are earned, although the taxpayers may not be aware of it.

\section{References}

Collier, Paul, 1995, The marginalisation of Africa, in: International Labour Review, 134, 4-5, 541-

Hansohm, Dirk, Klaus Schade, and Arne Wiig, 2001, Trade policy, poverty and inequality in Namibia, in: Francis Wilson, Nazneen Kanji and Einar Braathen (Eds), Poverty reduction. What role for the state in today's globalized economy? London/New York: Zed Books, 164-195

Moore, Mick, 1998, Death without taxes. Democracy, state capacity, and aid dependence in the Fourth world, in: Mark Robinson and Gordon White (Eds), The democratic developmental state, Oxford: Oxford University Press, 84-121

${ }^{3}$ One other area we did not touch on (due to limitations of both data and space) is the broad pattern of public expenditure. We only analysed some of those taxes whose benefits can be attributed to specific individuals. Although the link between taxes and expenditure makes sense intuitively, we are far from knowing enough about the precise incidence of taxation and expenditure to make firm statements. 
NEPRU, 1999, Reducing poverty and inequality, Windhoek, Viewpoint No. 22

Rakner, Lise, 2001, The politics of revenue mobilisation. Explaining continuity in Namibian tax policies, in: Forum for Development Studies, Vol. 28, No. 1, 125-145

UNDP, 2000, Human Development Report Namibia, Windhoek

World Bank, 2002, World Development Report 2002, New York: Oxford University Press 
Table 1 Sources of state revenue (\%): Namibia in comparative international context

\begin{tabular}{|c|c|c|c|c|c|}
\hline Source of income & $\begin{array}{c}\text { Low } \\
\text { income } \\
\text { countries }\end{array}$ & $\begin{array}{c}\text { Lower } \\
\text { middle } \\
\text { income } \\
\text { countries }\end{array}$ & $\begin{array}{c}\text { Upper } \\
\text { middle } \\
\text { income- } \\
\text { countries }\end{array}$ & $\begin{array}{c}\text { High } \\
\text { income } \\
\text { countries }\end{array}$ & Namibia \\
\hline A. Aid & 43 & 12 & 1 & Neg. & 14 \\
\hline $\begin{array}{l}\text { B. Taxes on international trade } \\
\text { and transactions }\end{array}$ & 17 & 18 & 13 & 2 & 28 \\
\hline C. Non-tax revenue & 9 & 16 & 11 & 10 & 8 \\
\hline $\begin{array}{l}\text { D. Domestic taxes on goods and } \\
\text { services }\end{array}$ & 16 & 25 & 32 & 27 & 27 \\
\hline E. Other taxes & 2 & 4 & 4 & 3 & 1 \\
\hline $\begin{array}{l}\text { F. Taxes on income, profit, and } \\
\text { capital gains }\end{array}$ & 13 & 21 & 24 & 34 & 22 \\
\hline G. Social Security Contributions & 1 & 4 & 14 & 24 & Neg. \\
\hline Total & 100 & 100 & 100 & 100 & 100 \\
\hline $\begin{array}{l}\text { (current revenue as a \% of } \\
\text { GDP) }\end{array}$ & $(17)$ & (23) & $(27)$ & $(37)$ & $(30)$ \\
\hline \multicolumn{6}{|c|}{ Government income from sources classified by degree of earnedness: } \\
\hline Very low (A) & 43 & 12 & 1 & Neg. & 14 \\
\hline Low $(B+C)$ & 26 & 34 & 24 & 12 & 36 \\
\hline Low and very low $(A, B$, and $C)$ & 69 & 46 & 25 & 12 & 50 \\
\hline Average $(\mathrm{D}+\mathrm{E})$ & 18 & 29 & 36 & 30 & 33 \\
\hline High $(\mathbf{F}+\mathbf{G})$ & 14 & 25 & 38 & 58 & 23 \\
\hline
\end{tabular}

Sources: Moore (1998: 100); Bank of Namibia and Central Statistics Office (last column)

Notes: The figures refer to 1988, except those for Namibia, which are the average of 1993-2002 i.e. the post-independence period. 
Figure 1 Expenditure structure by area (\% of total budget), 1995/96-2001/02

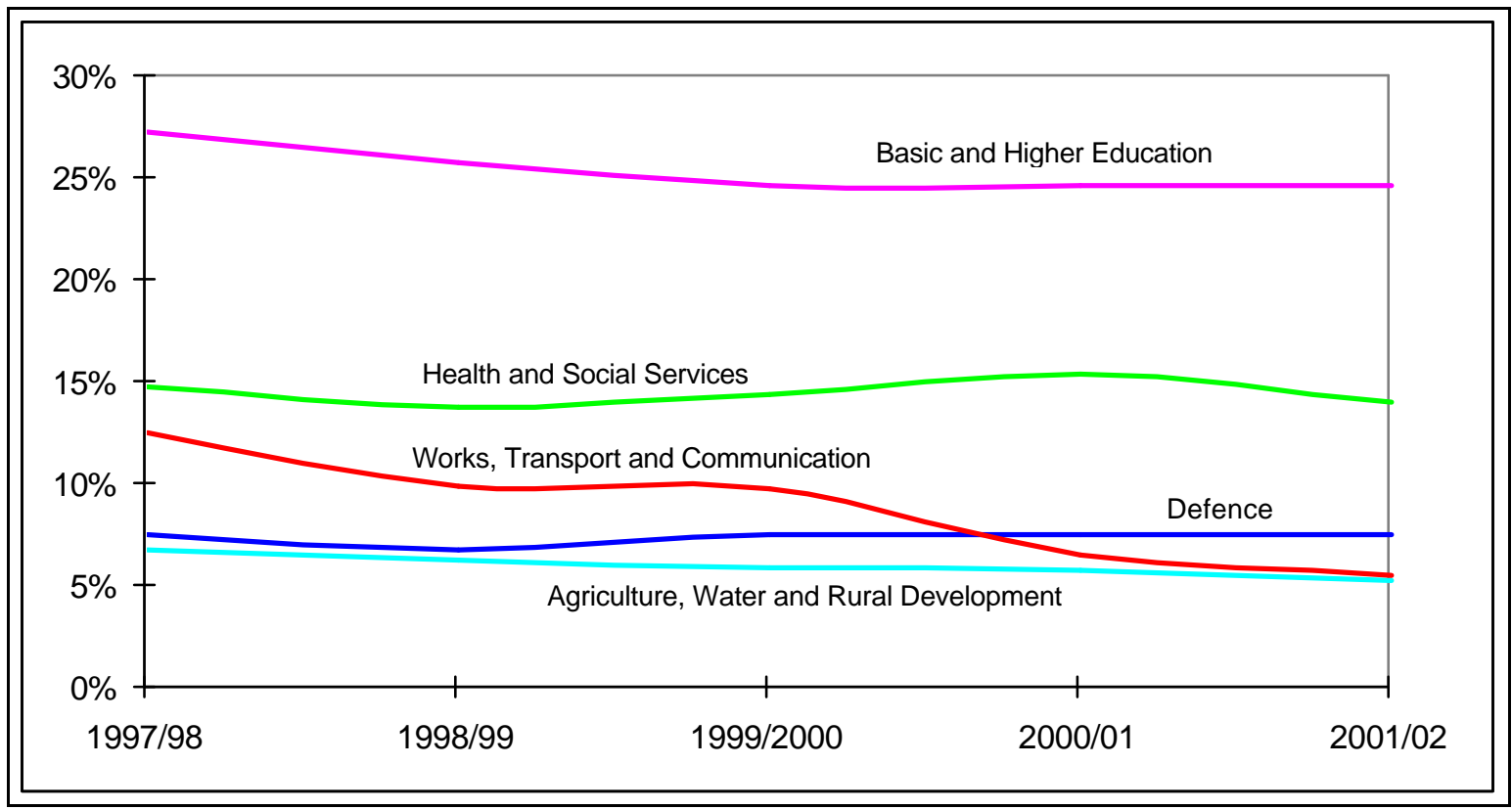

Source: $\quad$ Republic of Namibia 
Table 2 Regional distribution of government expenditure

\begin{tabular}{lrrrc}
\hline \multicolumn{5}{c}{ Public Development Budget 1996-2001, per capita by region (Namibian dollars) } \\
\hline \multicolumn{1}{c}{ Region } & $\mathbf{1 9 9 6}$ & $\mathbf{1 9 9 7}$ & $\mathbf{1 9 9 8}$ & $\mathbf{1 9 9 9}$ \\
\hline Khomas & 1160 & 873 & 812 & 994 \\
Caprivi & 689 & 643 & 391 & 763 \\
Oshikoto & 79 & 62 & 147 & 426 \\
Oshana & 203 & 62 & 114 & 423 \\
Karas & 609 & 489 & 442 & 395 \\
Erongo & 212 & 345 & 429 & 392 \\
Hardap & 110 & 32 & 24 & 361 \\
Ohangwena & 93 & 55 & 238 & 340 \\
Omaheke & 73 & 148 & 102 & 266 \\
Kavango & 281 & 367 & 340 & 232 \\
Otjozondjupa & 314 & 474 & 283 & 230 \\
Kunene & 439 & 257 & 257 & 194 \\
Omusati & 111 & 117 & 138 & 118 \\
\hline Namibia & $\mathbf{3 4 4}$ & $\mathbf{2 9 7}$ & $\mathbf{2 9 6}$ & $\mathbf{4 1 0}$ \\
\hline
\end{tabular}

Source: UNDP 2000 